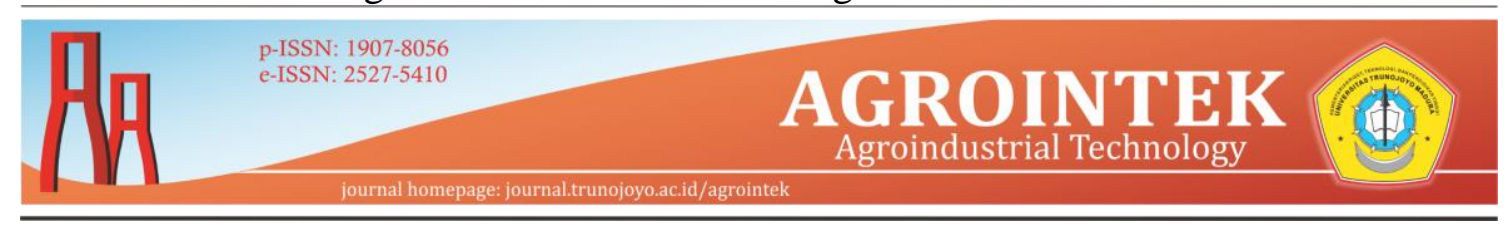

\title{
USULAN PERBAIKAN TATA LETAK FASILITASPRODUKSI KUE KERING DI PT. SURYA INDAH FOOD MULTIRASA
}

\author{
Afrida Nur Aini ${ }^{1}$, Raden Faridz $^{1 \dagger}$, Iffan Maflahah ${ }^{1}$ \\ ${ }^{1}$ Program Studi Teknologi Industri Pertanian, Universitas Trunojoyo Madura, Bangkalan
}

Article history

Diterima: 14 Juni 2019

Diperbaiki:15 Juli 2019

Disetujui:29 Juli 2019

$\underline{\text { Keyword }}$

facility,

layout,

blocplan method

\begin{abstract}
The design of facility layout in an industry becomes an important part of the production process. The layout of pastry facilities at "PT Surya Indah Food Multi rasa" is expected not still give optimum results because of in nonsequential production flows that occur in the formation of dough, oven, squash and finished products. The purpose of the study was to make a layout that fits the order of process flow by designing through the Blocplan-90 application. The study was conducted in November 2018 until February 2019. The Blocplan method is one of an easy computer operating the system by using manually entering facility data. The data needed is in the form of a map of the operation process, a linkage diagram of activities. The results of the initial layout data processing resulted in $R$-Score 0.78 and the proposed improvement with automatic search resulted in $R$-Score 0.98 . The design of the proposed improvement is more optimal with the value of $R$-Score approaching the value of 1(one). Changes in the layout of the facility occur in squash which is closer to mixing and weighing materials and oven facilities close to the finished product.

(C) hak cipta dilindungi undang-undang
\end{abstract}

\footnotetext{
$\dagger$ Penulis korespondensi

Email: rafasasraningrat@gmail.com

DOI: http://dx.doi.org/10.21107/agrointek.v13i2.5405
} 


\section{PENDAHULUAN}

Indonesia dengan penduduk sekitar 260 juta jiwa lebih adalah negara berpenduduk terbesar ke empat di dunia (Indonesia Investments, 2017), dan dengan rata-rata peningkatan jumlah penduduk sebesar empat juta per tahun (Ekarina, 2018), merupakan potensi besar dan akan mendongkrak pertumbuhan industri makanan dan minuman di Indonesia yang diprediksi pada tahun 2019 akan tumbuh sebesar $8 \%-9 \%$.

Menurut Badan Pusat Statistik Industri makanan di Jawa Timur pada tahun 2013-2015 terjadi peningkatan jumlah industri masing-masing sebanyak 1.724, 1.801 dan 1.843 industri.

Surya Indah Food Multirasa adalah salah satu industri pangan yang ada di Jawa Timur tepatnya kota Jombang. Usaha yang dikelola oleh industri ini meliputi berbagai kegiatan yaitu: produksi kue kering, katering serta menjadi distributor minuman dan pengemasan makanan. Industri ini telah mendapatkan piagam bintang satu dalam lingkup keamanan pangan dari Badan Pengawas Obat dan Makanan (Dinas Kesehatan Kabupaten Jombang 2014).

Surya Indah Food Multirasa dibangun, dirancang dan dikembangkan oleh pemiliknya sendiri setahap demi setahap berdasarkan pengalaman membuat kue yang telah ditekuninya bertahun-tahun dan disesuaikan dengan kebutuhan, sehingga tata letaknya secara operasional menyesuaikan dengan jenis proses kegiatan yang diperlukan. Pola operasional dan alur proses yang tidak ditata sejak awal pada perusahaan ini memungkinkan tingkat efisiensinya belum optimal jika dibandingkan dengan tata letak yang telah diatur dan dirancang sejak awal terutama dalam aktivitas pemindahan bahan yang menurut Wignyosubroto, (2003) dapat mendominasi kegiatan sistem produksi sebesar $50 \%-70 \%$.

Tata letak pabrik menurut Apple (1990) menjadi bagian penting dari sistem produksi karena akan mendukung kelancaran proses produksi. Lebih jauh dikemukakan oleh Apple (1990) berbagai aktifitas yang dapat mendukung kelancaran tersebut berupa pengaturan fasilitas-fasilitas pabrik. Pengaturan tersebut dapat dilakukan dalam bentuk pemanfaatan luas areal (space) untuk penempatan mesin, atau fasilitas pendukung produksi lainnya, keluasaan pergerakan bahan, penyimpanan bahan (storage) baik yang bersifat sementara maupun permanen, pekerja dan sebagainya. Peranan tata letak ini penting karena menentukan efisiensi sebuah proses operasi dan jangka panjang akan berdampak pada pada masalah ekonomi perusahaan (Heizer dan Render, 2006; Handoko, 2000)

Surya Indah Food Multirasa sebagai industri pembuat kue kering layaknya industri lainnya, terdapat beberapa kegiatan yang harus dilakukan seperti: persiapan bahan, pencampuran bahan, pencetakan, pengovenan dan pendinginan serta pengemasan (Sufi dan Harmono, 2007).

Kegiatan produksi kue kering yang dilakukan oleh industri ini dalam sehari dapat menghasilkan lebih kurang $20-23$ toples dengan isi 60 biji. Merujuk pada awal pendiriannya dan kesesuaian tata letak fasilitas (alat) yang digunakan dalam baku pembuatan kue, terdapat ke tidakberurutan dalam aliran prosesnya yaitu pada letak fasilitas pembuatan (pembentukan) adonan, pelumatan (pengulenan) dan pengovenan yang dapat menjadi sumber kurang optimalnya pengerjaan pembuatan kue seperti ditunjukkan pada Gambar 2. 
Gambaran tentang proses tersebut dapat dilihat dari penempatan tempat pencampuran yang kedudukannya lebih dekat dengan tempat pembentukan adonan dibandingkan pengulenan. Begitupun proses pengovenan yang lebih dekat dengan pengulenan dibandingan dengan tempat produk jadi.

Sebagai upaya untuk melakukan pengaturan kembali tata letak (relayout) fasilitas, terdapat banyak metode yang dapat digunakan seperti: algoritma CRAFT, CORELAP dan BLOCPLAN. Alternatif metode yang mendukung sistem perancangan fasilitas produksi adalah metode Blocplan. Pemilihan metode ini karena sistem pengoperasiannya yang mudah dan pengguna dapat secara manual memasukkan fasilitas serta keterkaitan hubungan sebagai pertimbangan pertukaran lokasi pada aliran proses kerja sehingga diperoleh proses yang maksimal (Ristono 2010).

\section{METODE}

Kegiatan penelitian ini dilaksanakan mulai bulan November 2018 - Februari 2019. Penelitian ini dilakukan pada PT. Surya Indah Food Multirasa. Tahapan penelitian dimulai dari observasi kondisi awal tata letak fasilitas dan peta proses pembuatan kue kering untuk mengetahui urutan proses pengerjaan dan penilaian keterkaitan hubungan antar fasilitas.

Pengolahan data meliputi perancangan alasan derajat kedekatan, peta keterkaitan kegiatan, diagram keterkaitan aktivitas dan mengaplikasikan pada software BLOCPLAN (Block Layout Overview with Layout Planning).

\section{HASIL DAN PEMBAHASAN}

\section{Peta Proses Operasi Pembuatan Kue} Kering

Pembuatan kue kering pada PT. Surya Indah Food Multirasa mempunyai beberapa tahapan proses. Peta proses operasi pada pembuatan kue kering dapat dilihat pada Gambar 1.

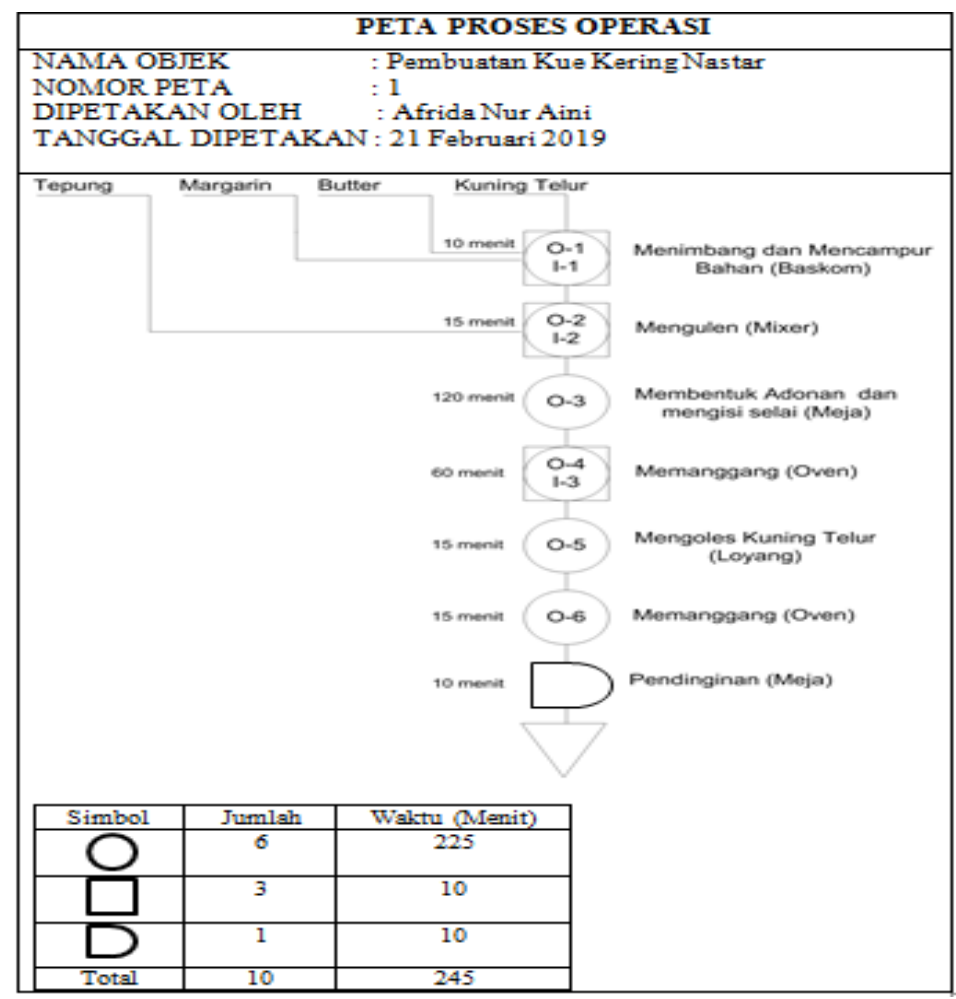

Gambar 1 Peta Proses Operasi Pembuatan Kue Kering 


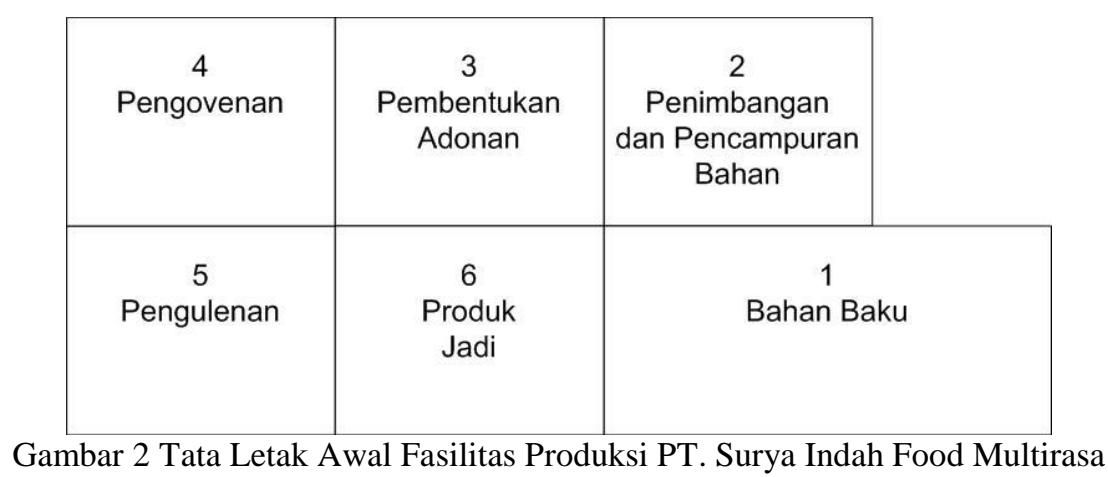

Tata Letak Fasilitas Produksi Kue Kering

Proses produksi kue kering berdasarkan tata letaknya terdiri dari enam kategori yaitu: penerimaan bahan baku, penimbangan dan pencampuran bahan baku, pembentukan adonan, pengulenan (pelumatan) adonan, pemanggangan (pengovenan) dan pemilahan produk jadi. Secara operasional tata letak (layout) awal disusun sesuai pada Gambar 2, dimana fasilitas sarana produksi berupa sistem alat dan peralatan disesuaikan mengikuti tata letaknya.

Berdasarkan pada proses produksi pembuatan kue terdapat beberapa tempat untuk penempatan fasilitas meliputi:

\section{Tempat Penyimpanan Bahan Baku (Tempat 1)}

Luas berukuran 8,9 × $3 \mathrm{~m}$ dengan fasiltas satu rak bahan baku ukuran 2 x 1 $\mathrm{m}$, tempat loyang $1,5 \times 1 \mathrm{~m}$ dan satu lemari pendingin/ kulkas berukuran $2 \times 1$ $\mathrm{m}$.

2. Tempat Penimbangan dan Pencampuran Bahan (Tempat 2)

Tempat dimana bahan dasar (telur, gula, royal) dicampur menggunakan mixer serta bahan baku utama (tepung) ditimbang. Pada ruangan ini berukuran 3,7 $\mathrm{x} 5 \mathrm{~m}$ yang terdapat alat dapur yang diperlukan dalam proses produksi sehingga memudahkan saat pencampuran dan penimbangan. Terdapat fasilitas satu meja pencampuran ukuran $2 \times 1 \mathrm{~m}$, dua rak peralatan dapur 1 x $1 \mathrm{~m}$ yang dapat membantu jalannya proses penimbangan dan pencampuran serta tempat pencucian berukuran $0,5 \times 2 \mathrm{~m}$.

\section{Tempat Pembentukan Adonan (Tempat 3)}

Tempat ini digunkan untuk melakukan proses membentuk adonan menjadi bulatan kecil serta pengisian selai pada kue. Luas tempat ini berukuran 3 x 4 $\mathrm{m}$ terdapat fasilitas 2 meja pembentukan adonan masing-masing berukuran $2 \times 0,7$ $\mathrm{m}$.

\section{Tempat Pengovenan (Tempat 4)}

Tempat dilakukannya proses pemanggangan kue yang berukuran 1,9 x $4 \mathrm{~m}$. Pemanggang dengan masing-masing berukuran 0,6 x $1 \mathrm{~m}$ dapat digunakan untuk 2 loyang.

\section{Tempat Pengulenan (Tempat 5)}

Ruang Pengulenan ini berukuran 1,9 x $4 \mathrm{~m}$. Tempat ini merupakan lokasi proses dimana adonan yang telah dicampur kemudian dikaliskan dengan pengulen atau mesin mixer Planetary berukuran 0,6 x 0,6 m. Mesin memiliki kapasitas adonan 8-10 kg dalam satu kali produksi.

\section{Tempat Produk Jadi (Tempat 6)}

Tempat Produk Jadi yang memiliki luas $3 \times 4 \mathrm{~m}$ merupakan tempat dimana produk yang sudah didinginkan untuk selanjutnya dikemas pada satu meja pengemasan dengan ukuran $2 \times 1 \mathrm{~m}$. 
Analisis Perbaikan Peta Keterkaitan Aktivitas

Peta keterkaitan aktivitas atau activity relation charts (ARC) dalam setiap ruangan diberi kode dan kode huruf sesuai tingkat hubungan antar ruangan lain. Peta keterkaitan aktivitas (ARC) dapat dilihat pada Gambar 3

Beberapa kekurangan dikaji pada Gambar 2 dan Gambar 3 dari rancangan proses produksi dan peta keterkaitan awal pabrik antara lain:

Tempat 3 (Pembentukan Adonan) letaknya kurang strategis karena tidak sesuai dengan urutan aliran kerja (peta proses operasi) dan pemindahan bahan sehingga kemungkinan besar terjadi pemborosan tenaga yang dikeluarkan secara tidak disadari oleh pekerja.

Tempat 5 (Pengulenan) letaknya tidak sesuai dengan urutan peta proses operasi yang seharusnya lebih berdekatan dengan tempat 2 (Penimbangan dan pencampuran bahan).

Langkah untuk melakukan perbaikan tata letak proses pembuatan kue kering dilakukan berdasarkan hasil wawancara melalui kepala bagian produksi. Gambaran keterkaitan aktivitas perbaikan fasilitas produksi PT Surya Indah Food Multirasa sebagai hasil wawancara dapat dilihat pada Gambar 4.

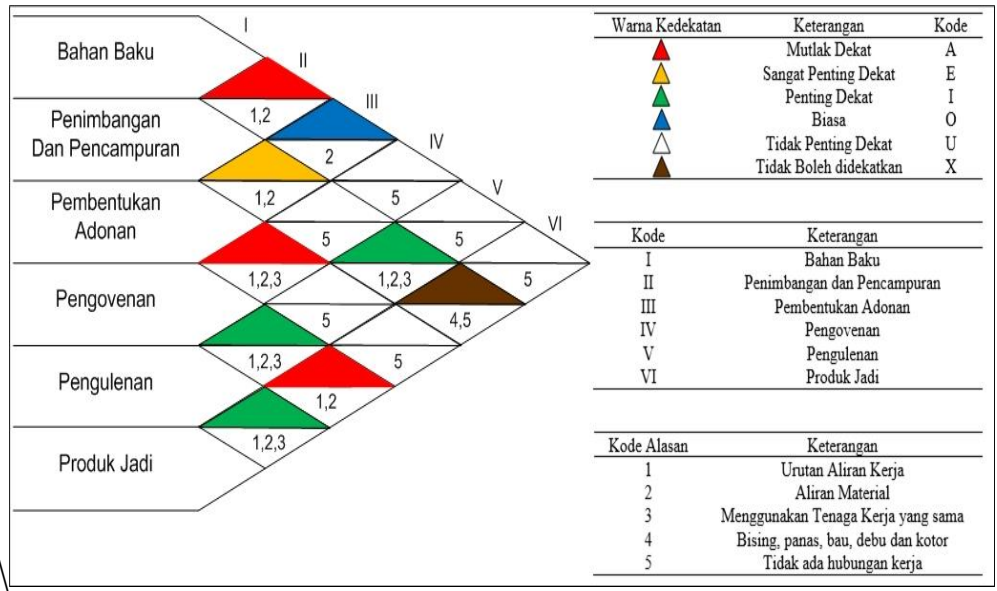

Gambar 3 ARC Awal Fasilitas Produksi PT Surya Indah Food Multirasa

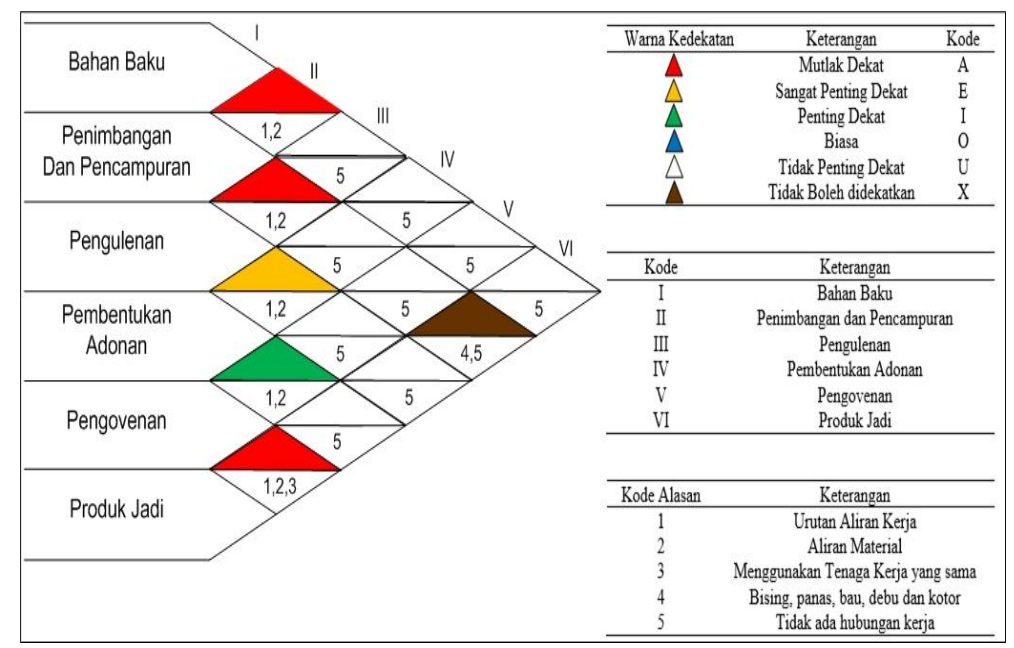

Gambar 4 ARC Usulan Fasilitas Produksi PT Surya Indah Food Multirasa 
Diagram Keterkaitan Aktivitas (ARD)

Pembuatan diagram keterkaitan aktivitas atau activity relationship diagram (ARD) pada perusahaan PT. Surya Indah Food Multirasa berasal dari peta keterkaitan aktivitas yaitu dengan cara mentransformasi hasil ARC ke dalam bentuk lembar kerja. Penilaian secara kualitatif disesuaikan dengan alasan derajat keterkaitannya. Lembar kerja keterkaitan aktivitas dapat dilihat Tabel 1.

Pembuatan lembar kerja keterkaitan aktivitas seperti ditunjukkan pada Tabel 1

Tabel 1 Lembar Kerja Keterkaitan Perbaikan Aktivitas

\begin{tabular}{llcccccc}
\hline No & \multicolumn{1}{c}{ Ruangan } & \multicolumn{5}{c}{ Derajat Keterkaitan } \\
\cline { 3 - 7 } & & E & I & O & U & X \\
\hline 1 & Bahan Baku & 2 & - & - & - & $3,4,5,6$ & - \\
2 & $\begin{array}{l}\text { Penimbangan } \\
\text { dan }\end{array}$ & 1,3 & - & - & - & 4,5 & 6 \\
& Pencampuran & & & & & & \\
3 & Pengulenan & 2 & 4 & - & - & $1,5,6$ & - \\
4 & Pembentukan & - & 3 & - & - & $1,2,5,6$ & - \\
& Adonan & & & & & & \\
5 & Pengovenan & 6 & - & 4 & - & $1,2,3$ & - \\
6 & Produk Jadi & 5 & - & - & - & $1,3,4$ & 2 \\
\hline
\end{tabular}

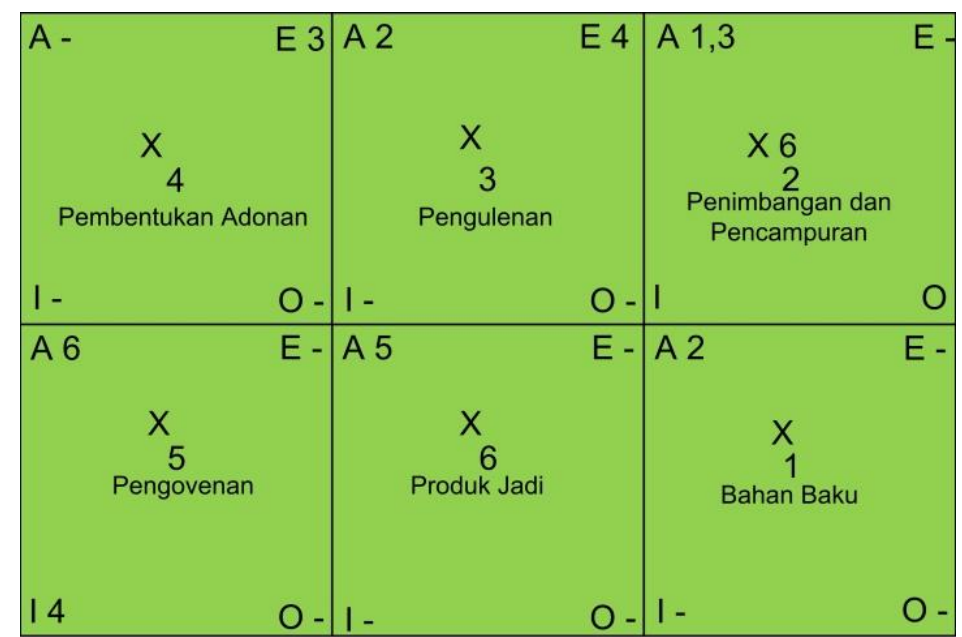

Gambar 5 Lembar Kerja Diagram Keterkaitan Aktivitas Fasilitas PT. Surya Indah Food Multirasa bertujuan untuk mempermudah dalam penyusunan ARD seperti ditunjukkan pada Gambar 5.

Bentuk lembar diagram keterkaitan aktivitas fasilitas proses produksi yang diperlihatkan oleh Gambar 5, kode huruf $\mathrm{U}$ tidak dimasukkan, karena dianggap tidak memberikan pengaruh terhadap keterkaitan. Selanjutnya dibuat Gambar 6 merupakan ARD fasilitas proses produksi sebagai usulan perbaikan pada PT. Surya Indah Food Multirasa. 


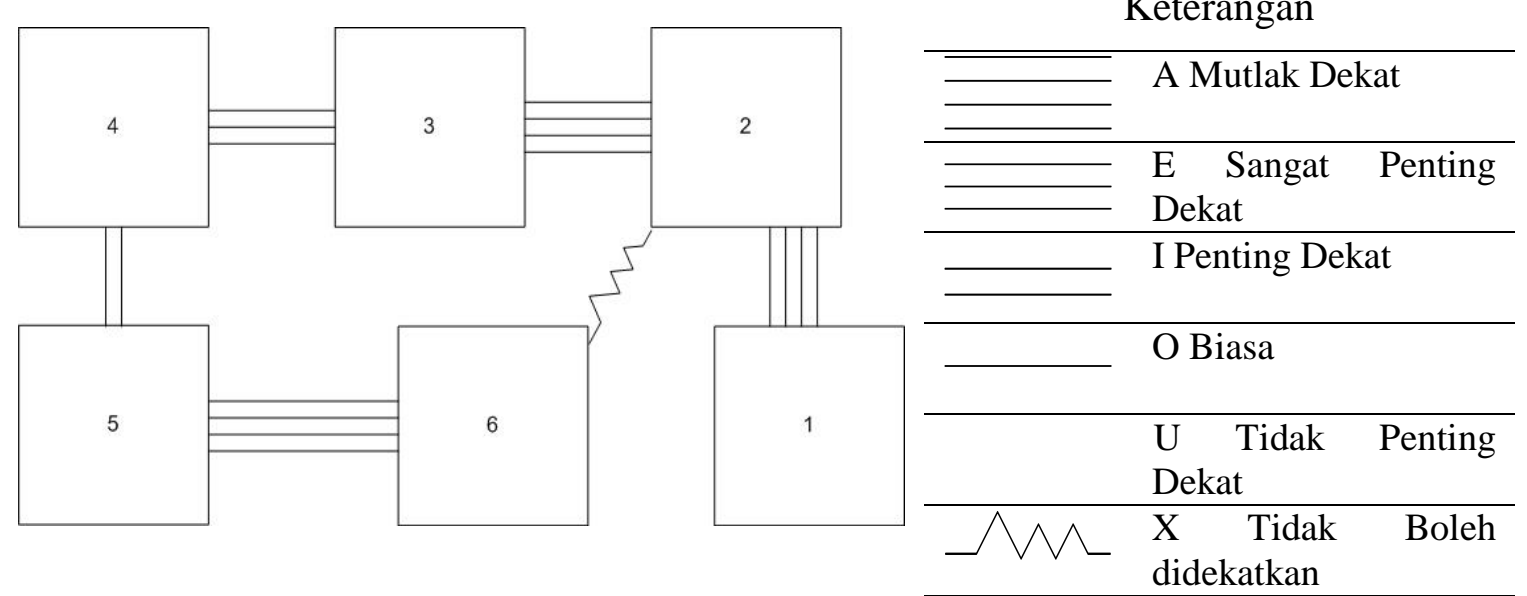

Gambar 6 ARD Fasilitas Produksi Usulan Perbaikan PT. Surya Indah Food Multirasa

Hasil dari template yang diperlihatkan dalam bentuk lembar kerja ARD (Gambar 5), selanjutnya dihubungkan dengan simbol-simbol berupa garis-garis yang memperlihatkan gambaran bagaimana keterkaitan dan keeratan hubungan antar fasilitas proses produksi seperti ditunjukkan oleh Gambar 6.

\section{Analisis Tata Letak Perbaikan Fasilitas Proses Produksi dengan Blocplan-90}

Gambar 7 berikut memperlihatkan bentuk aplikasi perancangan tata letak menggunakan aplikasi software Blocplan90, yang menggambarkan bagaimana bentuk hubungan antar aktifitas atau ARC, bersamaan dengan itu ditentukan pula luas setiap ruang yang digunakan dalam proses produksi. Selanjutnya mengacu pada layout awal perusahaan sebagai input data pada ARC menggunakan Blocplan dapat diketahui hasilnya seperti dalam Tabel 2

Tabel 2 menunjukkan bahwa layout score awal menggunakan Blocplan menghasilkan 0.78 dengan jarak kedekatan 107 - 1. Pada pengolahan data kualitatif ARC perbaikan melalui menu pilihan Blocplan dipilih single story layout menu. Single story layout merupakan menu dimana data kualitatif dimasukkan, tersimpan dan dapat diganti jika ada perbaikan. Langkah selanjutnya, dalam mencari layout optimal dan proses output yang cepat pada letak terbaik dengan menggunakan menu automatic search. Secara acak menu tersebut akan menunjukkan 20 layout dengan berbagai score layout. Hasil pencarian automatic search dalam menu single story layout ditunjukkan oleh Tabel 3.

Tabel 3 menunjukkan alternatif penyelesaian tata letak dengan kriteria untuk pemilihan alternatif tata letak adalah adjacency score (nilai hubungan kedekatan), R-score (efisiensi layout) dan Relative distance (jarak). Menurut Jaya et al., (2017) nilai R-Score (normalized relationship distance score) yang mendekati nilai 1 menunjukan bahwa layout tersebut optimal. Nilai adjacency score (nilai hubungan kedekatan) dengan mendekati nilai $1.00-1$ terdapat pada layout nomor $1,2,3,4,6,7,8,10,12,13$, $14,15,16,18$ dan 20. Pada layout nomor 14 dengan nilai R-score 0.98 karena mendekati nilai 1 dengan jarak kedekatan 38 - 3. Hal ini menjadikan R-score 0.98 merupakan layout terbaik dari 20 layout secara automatic search pada blocplan. Hasil layout dapat dilihat Gambar 7. 


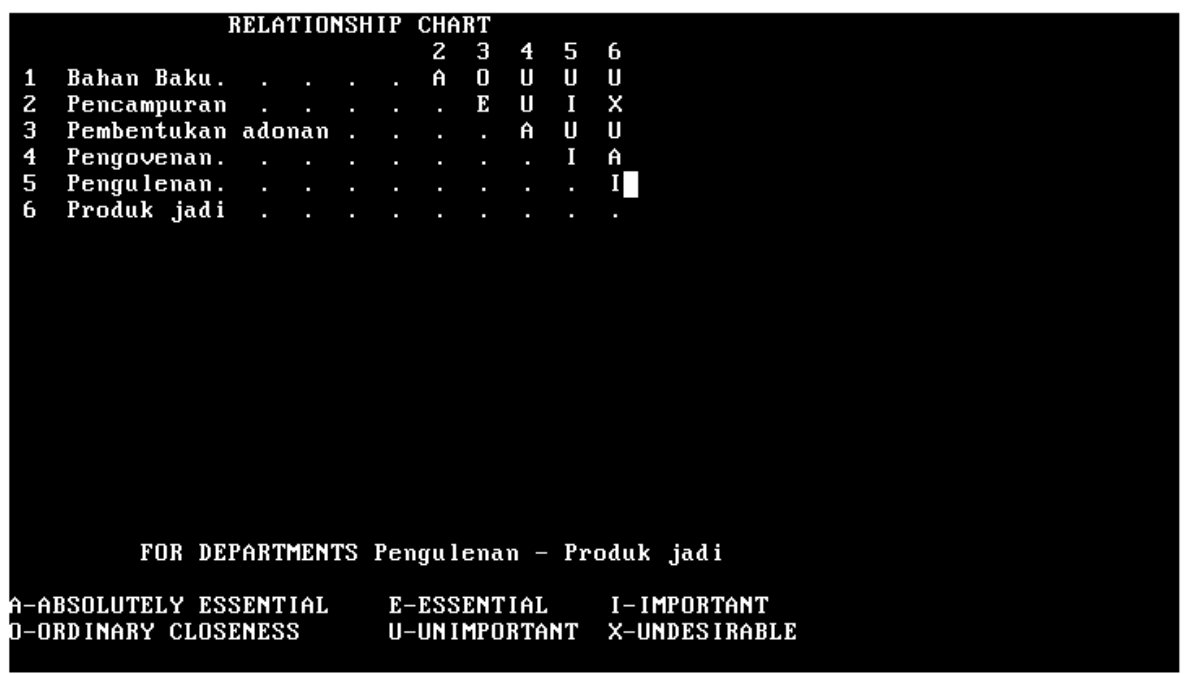

Gambar 7 Peta Keterkaitan Aktivitas software Blocplan 90

Kelebihan dan Kelemahan Usulan Perbaikan Fasilitas Produksi PT Surya Indah Food Multirasa

Pada usulan perbaikan fasilitas tedapat kelebihan dan kekurangan dalam penempatannya. Kelebihan dari layout usulan perbaikan fasilitas, setiap fasilitas yang berdekatan memiliki kaitan urutan proses kerja. Hal tersebut mempermudah dalam jalannya proses produksi kue kering. Tahapan proses produksi yang berurutan akan mengurangi kesenjangan pada pekerja seperti keletihan akibat bolak-balik dari tempat satu ke tempat lain dan waktu pengerjaan lebih optimal. Perubahan tata letak fasilitas terjadi pada pengulenan yang lebih dekat dengan pencampuran dan penimbangan bahan serta fasilitas pengovenan dekat dengan produk jadi.

Kekurangan dalam usulan perbaikan layout fasilitas, luas ruangan yang terbatas mengakibatkan kesulitan dalam perpindahan posisi tahapan proses usulan. Pada usulan perbaikan tidak diperhitungkan terkait ongkos material handling sehingga belum diketahui biaya perpindahan dalam masing-masing keterkaitan.

\section{KESIMPULAN}

Dari penelitian yang telah dilakukan dapat diambil kesimpulan sebagai berikut:

1. Urutan tata letak fasilitas kue kering adalah berupa tempat bahan baku, penimbangan dan pencampuran, pengulenan, pembentukan adonan, pengovenan dan produk jadi.

2. Perancangan usulan perbaikan fasilitas PT Surya Indah Food Multirasa menggunakan Blocplan90 menghasilkan rancangan usulan lebih optimal dibandingan layout awal karena R-score mendekati nilai 1 dengan jarak kedekatan 383. Perubahan tata letak fasilitas terjadi pada pengulenan yang lebih dekat dengan pencampuran dan penimbangan bahan serta fasilitas pengovenan dekat dengan produk jadi.

\section{SARAN}

Pada PT Surya Indah Food Multirasa perlu dilakukan penataan terhadap fasilitas seperti tempat loyang, bahan baku dan peralatan lainnya supaya tidak terjadi penumpukan diberbagai fasilitas produksi. 


\section{DAFTAR PUSTAKA}

Apple, M.J. 1990. Tata Letak Pabrik dan Pemindahan Bahan Edisi Ketiga. Bandung: ITB.

Badan Pusat Statistik. 2018. Banyaknya Industri Besar dan Sedang Menurut KBLI 2 Digit di Jawa Timur tahun 2011-2015. Jawa Timur: Badan Pusat Statistik.

Dinas Kesehatan Kabupaten Jombang. 2014. Profil Kesehatan Kabupaten Jombang Tahun 2014. Jombang: Dinas Kesehatan Kabupaten Jombang.

Ekarina, 2018. https://katadata.co.id/berita/2018/11/ 12/tahun-politik-2019-industrimakanan-minuman-diprediksitumbuh-stagnan. Diakses Jumat, 19 juli 2019; Pukul 10:41

Handoko, H. T., 2000. Dasar dasar Manajemen Produksi dan Operasi. BPFE, Yogyakarta.

Heizer, J. dan Render. B., 2006. Manajemen Operasi, Edisi Ketujuh. Salemba Empat, Jakarta.

Heragu, S., 1997. Facilities Design, PWS Publishing Company, Boston.

Indonesia Investments, 2017. Penduduk Indonesia. https://www.indonesiainvestments.com/id/budaya/pendudu k/item67? Diakses Tanggal 16 Juli 2019, Pukul 13:04.

Jaya, J. D., Nuryati dan Audinawati, S.A.N. 2017. Perancangan Ulang Tata Letak Fasilitas Produksi UD. Usaha Berkah Berdasarkan Activity Relationship Chart (ARC) dengan Aplikasi Blocplan-90. Jurnal Teknologi Agro-Industri. 4(2): 111123.

Ristono, A. 2010. Perancangan Fasilitas. Graha Ilmu, Yogyakarta.

Sufi, S.Y dan Harmono, J. 2007. Panduan wirausaha membuat kue kering. Agromedia Pustaka, Jakarta.
Wignjosoebroto, S. 2003. Tata Letak Pabrik dan Pemindahan Bahan. Guna Widya, Surabaya 